\title{
Globalisation In Nigeria's Oil And Gas Sectors, 1956-2011: An Analysis
}

\author{
Grace Malachi Brown, $P h D$ \\ Lecturer, Department Of History And Diplomatic Studies, Faculty Of Humanities, \\ Ignatius Ajuru University Of Education, P.M.B. 5047, Rumuolumeni, Port Harcourt, Rivers State, Nigeria
}

\begin{abstract}
The study appraises globalization in Nigeria's oil and gas sectors from 1958-2011. It also examines the various laws regulating the Nigeria's oil and gas sectors, its historical background and key aspects of economic globalization, such as financial, trade and investment liberalization, etc, in the face of the Nigeria's Niger Delta crises to the international community. A comparison or analysis will be made on these laws regulating the oil and gas sectors in Nigeria with other European countries and conventions so as to ascertain whether royalties, damages and compensation are directly paid to the oil and gas producing communities or to the state. The theoretical approach of this paper will focus on the analysis that Structural Adjustment Programme (SAP) seeks capitalist laissez-faire within a country. The findings of this study goes under the euphemism of deregulation or market-friendly policy, by responding to Adam Smith and the Laissez-faire bourgeois thinkers and using the Nigeria's Niger delta crises as a case study. The paper concludes that the clamour for a fairer revenue allocation and agitations by oil and gas producing communities in Nigeria's Niger Delta region would not have arisen if the Nigerian government repeal or review the laws regulating the oil and gas sectors. Also, if the multinational oil and gas companies operating in Nigeria are directly answerable to the oil and gas producing communities and pay them directly as obtainable in other European countries, it would have reduced their agitation, selfish interest, human right violations, insecurity and environmental degradation, etc, being suffered by these communities.
\end{abstract}

\section{Introduction}

Despite the fact that Nigeria has generated over $\$ 800$ billion from oil and gas from 1960s till date, the country is facing serious economic problems, poverty and unemployment. Oil Spills, waste dumping and gas flaring are undermined in the Niger Delta region of Nigeria that are producers of oil and gas in Nigeria (Amnesty International Report, 2009:2). Various economic policies and theories are unworkable in Nigeria, such as the Structural Adjustment Programmes (SAP), World Trade Organization (WTO) on protectionism and the advocacy by it of a new open door policy and the free trade ideas. These economic policies has ignored the historical process by which a particular state of advantage in natural resources, labour ability or being a trading country coins to be established. Why has these economic policies been unworkable in Nigeria? Recent analysis has shown that a plethora of social movements or militancy grew out of the space created by the Niger Delta crises and it is evident that the politics of petro-gas has shifted from a strategy of economic development to one of the international and global security between 1990 and 2009. In 2003 alone, the Nigerian government lost an estimated \$7 billion; by 2008 the amount had risen to almost $\$ 34$ billion (Abide, 2009). Nigeria's Senator David Dafinone has argued against the N444.8 billion allocations in the Nigeria's 2008 budget in the Niger Delta stating that it will not achieve the desired result (Vanguard, 2008). The study will examine the nature of economic globalization, some of its key aspects (financial, trade and investment liberalization, etc) in the face of the Niger Delta crises to the international community.

\section{Historical Background Of The Oil And Gas Sector}

Oil prospecting began in Nigeria as far back as 1908, when a German company, the Nigerian Bitumen Corporation started exploration in the Araromi area of the present Ondo State (Nigerian National Petroleum, Corporation, 1993). The pioneering efforts of this company, however, ended with the outbreak of the First World War in 1914. In 1937, oil prospecting resumed in Nigeria. Shell D'Arcy (the forerunner of the present Shell Petroleum Development Company of Nigeria) was awarded the sole concessionary rights covering the whole territory of Nigeria. Their activities were again interrupted by the Second World War, but resumed in 1947. As a result of the obnoxious section 6 (1)(a) of the Mineral Ordinance 1948, the Nigerian oil industry did not develop significantly. This section prevented non-British companies that were not headquartered in Britain from oil exploration. The same section also restricted oil exploration to British citizens only. It was not until after the Mineral ordinance was repealed that Nigeria Oil Industry was able to witness tremendous changes.

In 1962, with a view to regulating the Nigerian oil industry, vis a vis safety, the Mineral Oil (Safety Regulations) was promulgated. In 1963, the Regulation (Mineral Oil, Safety Regulations, 1962) was repealed. 
The repealing had a retroactive effect since it became operative as from 1962. Under the Mineral Ordinance of 1948, section 3 specifically vests ownership of mineral oil in the crown. Also, the right to explore was also restricted (Cap 120, Mineral Ordinance, 1948, Section 19 Petroleum Profit Tax Act, 1959).

However, it was not until 1956 that oil was discovered in commercial quantities at Oloibiri in the Niger Delta after several years of search and an investment of over N30 Million. Shell started oil production and export from its Oloibiri field in 1958 (Nigerian National Petroleum Corporation Diary, 1993). By 1961, other companies such as Mobil, Elf, Gulf, Texaco/Chevron and Pan-Ocean (Petroleum Act, 1969) had began exploration rights which had formerly been granted to Shell alone, was now extended to the newcomers in line with the government's policy of increasing the pace of exploration in the country (Etikerentse, 1985).

Oil production and export from the Oloibiri field was first started in 1958 by Shell at a production rate of 5,100 barrels of crude oil per day. The quantity doubled the following year, and crude oil exports from Nigeria rose to 2.0 million barrels per day in 1972 and reached a peak of 2.4 million barrels per day in 1979 . Nigeria attained the status of a major oil procedure, ranking seventh in the world by 1972. Nigeria has since grown to become the sixth largest oil producing country in the world.

The oil industry in Nigeria must be seen as encompassing all those companies, including the Nigerian National Petroleum Corporation, together with its subsidiaries involved in petroleum operation (African Concord, 1990). Section 2 of the Petroleum Act, 1969 includes any person to whom the Minister has granted an oil exploration licence, oil mining lease and oil prospecting licence. Also included are persons in joint venture partnership or production sharing arrangements with the Nigerian National Petroleum Corporation or a service contractor.

The oil and gas industry has been marred by political and economic strife largely due to a long history of corrupt military regimes and complicity of multinational corporations, notably Royal Dutch Shell. Despite this, it was not until the early 1990s that the situation was given international attention, particularly following the execution by the Nigerian state of Ken Saro-Wiwa, a playwright and activist, that provoked the immediate suspension of Nigeria from the Commonwealth of Nations with regard to human right violations. The Nigerian government, oil corporations and oil-dependent western countries have been criticized as too slow to implement reforms aimed at aiding a desperately underdeveloped area and remediating the unsustainable environmental degradation that petroleum extraction has brought.

\section{Laws Regulating The Oil And Gas Sector In Nigeria}

An examination of the following laws regulating oil and gas industry activities in Nigeria will help us to ascertain why the Nigerian government and multinational oil companies have taken advantage to exploit the rights of people and communities in the Niger Delta region, thus:

(1) Section 44(3) of the Constitution of the Federal Republic of Nigeria 1999 provide as follows:

Notwithstanding the foregoing provisions of this section, the entire property in and control of all minerals, mineral oils and natural gas in under or upon any land in Nigeria, or in, under or upon the territorial waters and the Exclusive Economic Zone of Nigeria shall vest in the Government of the Federation and shall be managed in such manner as may be prescribed by the National Assembly".

(2) Section 1 of the Land Use Act, 1978 also provide as follows:-

Subject to the provisions of this Act, all land comprised in the territory of each state in the federation are hereby vested in the Governor of that State and such land shall be held in trust and administered for the use and common benefit of all Nigerians in accordance with the provisions of this Act"

(3) Petroleum Act, 1969, Section 1 Schedule 1 states thus:-

(a) The entire ownership and control of all petroleum in, under or upon any lands to which this section applies shall be vested in the state.This section applies to all land (including land covered by water) which

(a) is in Nigeria, or

(b) is under the territorial waters of Nigeria, or

(c) forms part of the continental shelf.

(5) Petroleum (Drilling and Production) Regulations 1969 section 1(1) states:-

Every application for an oil exploration licence,

oil prospecting licence or oil mining lease shall be

made to the Minister in writing on the appropriate

form as set out in the schedule to these regulations.

(6) Petroleum Profits Tax Act 1959 as amended by Petroleum Profits Tax Act No. 15 of 1973 (Part 111) section 2 states thus:- 
for the purposes of subsection (1) (b) of the value of any chargeable oil so disposed off shall be taken to be the aggregate of":-

(b) The value of that oil as determined for the purpose of royalty, in accordance with the provisions of any enactment applicable thereon and any financial agreement; or

(c) Arrangement between the Federal Government of Nigeria and the company.

(7) Associated Gas Re-Injection Act 1979 (as amended by Act 2008), Section 1 make all natural gas to belong to the federal government of Nigeria.

From the above enactments or legislation, it is obvious that all lands in Nigeria belong to the Government of Nigeria, who deals with the multinational oil companies to the exclusion of its citizenry. Thus, oil companies would ordinarily pay compensation to the following category of persons (Etikerentse, 1988):-

(a) Persons who had vested in the land before the commencement of the Land Use Act, 1978 (see Sections 48 and 49). It also means that if any person acquire the land (whether in urban or non-urban areas) of the Land Use Act, the Governor of the State by the provisions of Section 28 of the Land Use Act, can revoke the person's right of occupancy.

(b) By Section 29(2) of the Land Use Act, if the holder or occupier is a community, the Governor may direct that any compensation payable to it shall be paid to:-

(i) The community; or

(ii) To the chief or leader of the community in accordance with the customary law, or

(iii) Into some fund specified by the Governor for the purpose of being utilized or applied for the benefit of the community.

Other enactments or laws regulating the oil and gas sectors are:-

- $\quad$ Minerals Ordinance of 1914, Cap. 350, Laws of the Federation of Nigeria, 1990

- $\quad$ Oil in Navigable Waters Act, Cap.338, Laws of the Federation of Nigeria, 1990

- $\quad$ Petroleum Act, Cap 131, Laws of the Federation of Nigeria, 1990

- Petroleum Act, Cap 131, Laws of the Federation of Nigeria, 1990 as amended by the Federal Environmental Protection Agency Decree No. 59 of 1992 to include the following Regulations:

- $\quad$ Petroleum Regulations

- Petroleum (Drilling and Production) Regulations

- $\quad$ Petroleum Refining Regulations

- Oil Pipelines Act

- Federal Environmental Protection Agency Act

- Guidelines and Standards for Environmental Pollution Control in Nigeria

- $\quad$ National Environmental Protection (Effluent Limitation) Regulations, 1991

- National Environmental Protection (Pollution Abatement in Industries and

Facilities Generating Wastes) Regulations, 1991 - Section 1.15 of 1991

- Environmental Impact Assessment Decree

- Criminal Code Act

- Harmful Waste (Special Criminal Provisions, Etc) Decree 1988

- Sea Fisheries Decree

- Territorial Waters Act

- Explosives Act

- Oil Terminal Dues Act

Despite the above laws regulating the oil and gas sector, there are no specified formula for assessment of compensation or universally accepted amount in any law in Nigeria for persons or land owners whose lands are affected by oil and gas activities under the Petroleum Act as provided by Section 29(2) of the Land Use Act or the Public Lands Act, Cap. 167. Even where damages by way of compensation are awarded by our courts, in most cases they are hopelessly inadequate. How much money can compensate an individual for the loss of his land, being his source of livelihood or a community for the destruction of their farmlands, fishing rights together with the deaths that result from the drinking water of their polluted streams? The problems created by these laws 
or legislation violated the rights of people or communities in the Niger Delta region and which the federal government of Nigeria should explore other means such as restoration or restitution and reparation.

\section{The Impact Of Economic Globalisation}

Globalization refers to a world in which societies, cultures, polities and economies have, in some sense, come closer together. According to Giddens (1990:64) the concept can be defined as 'the intensification of worldwide social relations which link distant localities in such a way that local happenings are shaped by events occurring many miles away and vice versa'. Thus, the job of a coal miner in Britain may depend on events in South Africa or Poland as much as on local management or national government decisions.

But the concept does not just refer to global interconnectedness. Globalization is best understood as expressing fundamental aspects of time-space distanciation. Globalization concerns the intersection of presence and absence, the interlacing of social events and social relations "at a distance" with local contextualities (Giddens 1991:240). Harvey (1989: 240), too, refers to the fact that globalization describes our changing experience of time and space, or time-space compression'.First, more and more parts of the world are drawn into a global system and so are affected by what happens elsewhere. Second, there is a sense that we know what is happening elsewhere more quickly, which in turn affects our sense of space and place.

Frank and others (Amin et al, 1982) have proposed one strategy for satellites to overcome underdevelopment. This was a complete delinking from the world economy in order to promote genuine development. In other words, a morally meaningless local, doomed to perpetual stagnation, could be replaced by a completely autonomous local, blessed with inevitable development (Brenner 1977; Gulalp 1986).

The globalization of the world economy refers to the ability of capital to move freely across national boundaries (Ohmae 1991). Such 'hyper-mobility' undermines the ability of nation-states to direct so-called 'national economies (Radice 1984). This movement is said to be particularly strong for finance capital, which does not face the constraints of fixed locational costs associated with industrial capital. Facilitated by the development of the new communications technologies, finance capital can move rapidly around the globe, in the process undermining among other things the ability of nation-states to control their national currency. This is undoubtedly the most globalised form of economic activity, and it is in this sphere that writers have referred to the 'end of geography' (O'Brien 1991). From 1980 to 1990, the volume of cross-border transactions in equities grew from $\$ 120$ billion a year to $\$ 1.4$ trillion, and international bank lending stock rose from $\$ 324$ billion to \$7.5 trillion (Hoogvelt 1997: 787-80).

Worsley 1984: 339 observed thus:

Third World... is not a myth. The various meanings with which the term "Third World" has been invested show family resemblances, even though they do not fully coincide. They have, that is, a common reference in the real world out there: the unequal, institutionalized distribution of wealth and illth on a world scale..

\section{Also, Escobar 1995a:3 observed that:}

More than half the people of the world are living in conditions approaching misery. Their food is inadequate, they are victims of disease. Their economic life is primitive and stagnant. Their poverty is a handicap and a threat both to them and to more prosperous areas. For the first time in history humanity possess the knowledge and the skill to relieve the suffering of these people...I believe that we should make available to peace-loving peoples the benefits of our store of technical knowledge in order to help them realize their aspirations for a better life... What we envisage is a program of development based on the concepts of democratic fair dealing...Greater production is the key to prosperity and peace. And the key to greater production is a wider and more vigorous application of modern scientific and technical knowledge.

The result of this technocratic approach has been that people in the Third World have been treated as objects of development, rather than the makers of their own history, and the implementation of development within concrete social relations has had profoundly unexpected results (Kiely 1995). Development fostered a way of conceiving of social life as a technical problem, as a matter of rational decision and management to be entrusted to that group of people - the development professionals-whose specialized knowledge allegedly qualified them for the task. Instead of seeing change as a process rooted in the interpretation of each society's history and cultural tradition...these professionals sought to devise mechanisms and procedures to make societies fit a pre-existing model that embraced the structures and functions of modernity (Escobar 1995:52).

It is, however, appalling that the ingenuity of those proponents of the term 'globalisation' or its associated 'economic globalisation' has failed to transform the economic lives of the third world recipient of globalisation. Its disadvantageous effect transcends over the advantages. The Niger Delta region in whom communities the multinational companies are prospecting the oil and gas, are faced with abject poverty and lacked any form of development. Thus, this study will focus on the analysis that Structural Adjustment Programme (SAP) seeks capitalist Laissez-faire within a country. This study goes under the euphemism that deregulation or market 
friendly policy are unworkable. The Laissez-faire is based ultimately on individual self-interest and efficiency. Adam Smith looked at society atomistically as a mere collection of individuals. He thought that (a) self interest would necessarily lead to efficiency; and that (b) specialization and production enthusiasm would stimulate growth (Toyo, 2007:27). This study will respond to Adam Smith and the Laissez-faire bourgeois thinkers in the face of the Niger Delta crises, in the following manner thus:-

(1) Self interest is what everyone has, but self interest is different from efficiency. The latter may be predatory and corrupt. Capitalist interest is selfish interest rather than merely efficiency. It is sui-generis predatory and often corrupt.

Individual self interest ignores the existence of social interest. A society is not a mere sum of individuals. Opportunities for, interests of, and roles of individuals depend on the social organization and their positions and chances in it.

(2) Why should self interest be the interest to grab and accumulate wealth out of the work of others and at the expense of society?

It is not always the case that each adult is the best judge of his own self interest. An ignorant person is not necessarily the best judge of his own self interest. Science can expose myopia, bigotry or stupidity in the name of self interest. The usual qualification that each one should pursue his own self interest provided he does not run afoul of the interests of others is neither here nor there in bourgeois society. Under any arrangement the pursuit of greed is bound to run counter at one point or other to the interests of someone else.

(3) The concept of efficiency depends on the goal defined and how it is supposed to be attained. A static goal may be inefficient in dynamic terms. Money profit, is not necessarily the best or even a true test of efficiency. To pursue predatory goal efficiency may be more damaging to the interests of others. Moreover, if we scrutinize the Economics of Structural Adjustment in Nigeria respecting the Niger Delta crises, we will observe that there are several unworkable economic goals, such as economic independence, that are more fundamental than enterprise efficiency.

Apart from the philosophical arguments for laissez-faire, there were certain specific expectations from Structural Adjustment Programme (SAP). It was promised that it would halt capital flight, raise employment, greatly stimulate production and exports, lead to an impressive sustained growth, and reverse the trend in indebtedness. In all these respects it has disappointed the expectations of its trumpeters.

The theory on which free trade is based stems from a simple idea. Division of labour exits because specialization and exchange by specialists enhance output and potentially the welfare of the traders. If each country specializes in producing for the international market resources, man-produced resources or man-power, each country will gain better than otherwise and, therefore; all countries will be more prosperous.

A careful examination of the types of injuries suffered in the Niger Delta region as a result of oil and gas activities, shows that economic globalization has impacted negatively on the people.

The effects of globalization on the aforementioned resource conflicts and cultural wars in Nigeria have failed to live up to the rosy expectations many average Nigerians held for the future upon the first successful exportation of oil from the Niger Delta in 1958. Bade Onimode wrote in 1978 that globalization has "generated and perpetuated the seemingly intractable problems of mass poverty, stifling foreign domination, savage exploitation, open starvation, debilitating disease, pervasive illiteracy, widening inequality, irrational waste, cultural degradation and political instability in Nigeria." (Onimode, 2008). Thirty years later, Onimode looks like a visionary able to see ahead of her time. The Structural Adjustment Programmes of the World Bank and International Monetary Fund and the presence of Multinational Oil Companies (MNOCs) were supposed to help bring about sustainable development so that Nigeria could dig itself out of the black hole of problems that Onimode so accurately describes. Instead, Nigeria remains among the poorest countries in the world per capita despite having exported trillions of dollars worth of oil all around the world since 1958. The failure to uphold the social contract continues to this day as drilling and exploration still add up to the devastating exploitation of the Niger Delta's natural resources and the history and society of its inhabitants. Militants continue to clash with government forces in a perpetuation of the same resource conflicts that began with the civil war in 1967. No one can say with any certainty that Nigeria will not be able to fully capitalize on its natural resource wealth and turn it into a sustainable economy for the future of a world without oil, based less on exports and more on human capital. What we can say for certain, as oil prices drop below fifty dollars a barrel, is that without a drastic change in course, Nigeria is in danger of squandering the greatest natural resource the world has ever known.

\section{Types Of Injuries Suffered In The Niger Delta Region By Oil And Gas Activities In Nigeria}

The Niger Delta region is one of the most important wetland and coastal marine ecosystems in the world and is home to some 31 million people. The region consists of the following nine states in Nigeria: Rivers, Akwa Ibom, Bayelsa, Cross River, Abia, Edo, Delta, Imo and Ondo. It is the location of massive oil 
deposits, which have been extracted for decades by the government of Nigeria and by multinational oil companies. Oil has generated an estimated $\$ 600$ billion since the 1960 s (Daily Times, 2003).

In 2008, Amnesty International researchers documented the impact of oil pollution on human rights and visited a number of oil pollution sites and met with communities in the Niger Delta region who have suffered from pollution. They also talked with the human rights defenders and environmental activists who has been working for years, for an end to oil industry bad practice in the region, who have been campaigning for justice for those affected by pollution (Amnesty International Report, 2009). Oil spills, waste dumping and gas flaring are undermined in the Niger Delta. This pollution, which has affected the area for decades, has damaged the soil, water, and air quality (Etim, 2003). Hundreds of thousands of people are affected particularly the poorest and those who rely on traditional livelihoods such as fishing and agriculture (Okaba, 2005). The human rights implications are serious, under-reported and have received little attention from the government of Nigeria or the oil companies. This is despite the fact that the communities themselves and local NGOs as well as the African Commission on Human and People's Rights and the United Nations Human Rights Committee have all expressed serious concern about pollution and called on the government of Nigeria to take urgent action to deal with the human rights impacts of oil industry pollution and environmental degradation. In all cases, the multinational companies and the federal government has either failed, refused, delayed or neglected to pay adequate compensation to the communities in the Niger Delta that have suffered from oil and gas injuries under Section 11(5)@ of the Oil Pipelines Act on the basis of statutory strict liability. For example, it is over one the United Nation Environmental Project (UNEP) Report was published as a result of the pollution that occurred in Ogoniland in 2008, no compensation has been paid to the communities concerned. Paragraph 36 of Schedule 1 of the Petroleum Act, 1969 provides that:

The holder of an oil exploration licence, oil prospecting licence or oil mining lease shall, in addition to any liability for compensation to which he may be subject under any other provision of this Act be liable to pay fair and adequate compensation for disturbance of surface or other rights to any persons who orders or is in lawful occupation of the licenced or leased land.

Again, under Regulation 23 of the Petroleum (Drilling and Production) Regulation 1969, there are provisions for the payment of adequate compensation for the disturbance of fishing rights arising from pollution.

The violent conflict in the Niger Delta region of Nigeria has attracted the attention of world leaders, politicians, scholars, non-governmental organizations, and all sort of groups, tracing the causes to pollution and environmental degradation and also the unfavourable or weak laws regulating oil and gas exploration and which the multinational oil companies operating in Nigeria take advantage to exploit the oil producing communities who are directly affected by their activities, thereby violating their human rights and posing security threats in the region. Such human rights violation as reported by the Amnesty International (2009) includes:-

(1) Violations of the right to an adequate standard of living, including the right to food - as a consequence of the impact of oil-related pollution and environmental damage on agriculture and fisheries, which are the main sources of food for many people in the Niger Delta.

(2) Violations of the right to gain a living through work - also as a consequence of widespread damage to agriculture and fisheries, because these are also the main sources of livelihood for many people in the Niger Delta.

(3) Violations of the right to water - which occur when oil spills and waste materials pollute water used for drinking and other domestic purposes.

(4) Violations of the right to health - which arise from failure to secure the underlying determinants of health, including a healthy environment, and failure to enforce laws to protect the environment and prevent pollution.

(5) The absence of any adequate monitoring of the human impacts of oil-related pollution - despite the fact that the oil industry in the Niger Delta is operating in a relatively densely populated area characterized by high levels of poverty and vulnerability.

(6) Failure to provide affected communities with adequate information or ensure consultation on the impacts of oil operations on their human rights.

(7) Failure to ensure access to effective remedy for people whose human rights have been violated.

\section{Violent Conflicts In The Niger Delta Region}

Essentially, what the people of the Niger Delta want in 2009 is not so different from what the people of the area wanted as far back as 1951 or what other Nigerians have always wanted. Areas of correlation can be found in the demands of the Ijaw Youths Congress and demands on the Nigerian state by the Movement for the Survival of Biafra, the Arewa Youth Congress or the Odua Peoples' Congress. As citizens, the people of the Niger Delta are asking for equity and justice and due recognition of their rights as citizens. These are contained 
in the Ogoni Bill of Rights, the Kaiama Declaration and similar declarations by other groups in the Niger Delta (Adaka Boro Centre, 2009: 3)

Simplified, this includes first, the rights to control crude oil resources or at best to be accorded 50 per cent derivation. Second, the people are insisting on a cessation of deleterious oil exploration activities which destroy the Niger Delta ecology and human lives. Third, they want the abrogation of all laws which dispossess them of their rights as a federating unit inside Nigeria. Fourth, they want the crisis of poverty in the Niger Delta to be addressed.

With the oil boom becoming an oil burst and the failure of Nigerian Government to diversify its economy, the country's poverty index has risen sharply and there is poverty in the Niger Delta. Fifth, they want other Nigerians to listen to their message and treat them with respect as equal stakeholders in the Nigerian partnership arrangement.

The Niger Delta presents a curious paradox. The people live in coastal areas surrounded by water, and yet they cannot get potable water to drink. Their neighborhoods and creeks are littered with pipelines crisscrossing all the way through, bearing petroleum products to other parts of the country, but in this same Niger Delta fuel is scarce and expensive. The cost of petrol is higher in Yenagoa than in Kano. Revenue from crude oil sale is used to provide infrastructure in other parts of Nigeria: the beautiful roads in Abuja, the skyscrapers in Lagos, the flyovers across the country, but many communities in the Niger Delta are cut-off from civilization because there are no roads or bridges leading to them.

More jobs have been created in Europe and America on account of oil exploration activities in the Niger Delta whereas Niger Delta youths are largely unemployed. The qualified ones among them have to struggle with Yorubas and the Hausa-Fulani to get positions in the oil companies. Conveniently, the oil exploration companies have their head offices in Lagos and Abuja, not in the Niger Delta. Children just grow up and die in the Niger Delta with little hope about tomorrow, whereas children in other parts of Nigeria, attending schools built with oil wealth stand a much better chance. The Niger Delta people feel neglected and provoked. The militants among them have reached a point where the only choice they find attractive is to destroy the goose that lays the golden egg, simply because the goose is more useful to other people rather than its owners.

\section{(a) The Case of Ogoniland (1992-1995)}

Ogoniland is a 404 -square mile $\left(1,050 \mathrm{~km}^{2}\right)$ region in the southeast of the Niger Delta basin. Economically viable, petroleum was discovered in ogoniland in 1957, just one year after the discovery of Nigeria's first commercial petroleum deposit, with Royal Dutch Shell and Chevron Corporation setting up shop throughout the next two decades. The indigenous people of Ogoni and other ethnic groups in the region attest that during this time, the government began forcing them to abandon their land to oil companies without consultation, and offering negligible compensation. This is further supported by a 1979 constitutional addition which afforded the federal government full ownership and rights to all Nigerian territory and also decided that all compensation for land would "be based on the value of the crops on the land at the time of its acquisition, not on the value of the land itself". The Nigerian government could now distribute the land to oil companies as it deemed fit. (Human Right Watch, 1999).

Between 1970s and 1980s the government's promises to the people of Ogoni and the entire Niger Delta were not realizable, hence the people were dissatisfied and which led to the formation of the Movement of the Survival of the Ogoni People (MOSOP) in 1992. MOSOP, spearheaded by Ogoni playwright and author, Ken Saro-Wiwa, became the major campaigning organization representing the Ogoni people in their struggle for ethnic and environmental rights. Its primary targets, and at times adversaries, have been the Nigerian government and Royal Dutch Shell.

Beginning in December 1992, the conflict between Ogonis and the oil infrastructure escalated to a level of greater seriousness and intensity on both sides. Both parties began carrying out acts of violence and MOSOP issued an ultimatum to the oil companies (Shell, Chevron, and the Nigerian National Petroleum Corporation) which demanded some $\$ 10$ billion in accumulated royalties, damages and compensation, and "immediate stoppage of environmental degradation", and negotiations for mutual agreement on all future drilling. (Oputa Report, Vol. 2).

The Ogonis threatened to embark on mass action to disrupt their operation if the companies failed to comply. By this act, the Ogoni shifted the focus of their actions from an unresponsive federal government to the oil companies engaged in their own region. The rationale for this assignment of responsibility were the benefits accrued by the oil companies from extracting the natural wealth of the Ogoni homeland, and neglect from central government.

The government responded by banning public gatherings and declaring that disturbances of oil production were acts of treason. Oil extraction from the territory had slowed to a trickle of 10,000 barrels per day $\left(1,600 \mathrm{~m}^{3} / \mathrm{d}\right)(.55$ of the national total). 
Military repression escalated in May 1994. On May 21, soldiers and mobile policemen appeared in most Ogoni villages. On that day, four Ogoni chiefs (all on the conservative side of a schism within MOSOP over strategy) were brutally murdered. Saro-Wiwa, head of the opposing faction, had been denied entry to Ogoniland on the day of the murder, but he was detained in connection with the killings. The occupying forces, led by Major Paul Okuntimo of Rivers State Internal Security, claimed to be "searching for those directly responsible for the killings of the four Ogonis". However, witnesses say that they engaged in terror operations against the general Ogoni population. Amnesty International characterized the policy as deliberate terrorism. By mid-June, the security forces had razed 30 villages, detained 600 people and killed at least 40 . This figure eventually rose to 2,000 civilian deaths and the displacement of around 100,000 internal refugees. (Tobias HALLER, 2000).

In May 1994, nine activists from the movement who would become known as 'The Ogoni Nine', among them (Ken Saro-Wiwa, were arrested and accused of incitement to murder following the deaths of four Ogoni elders. Saro-Wiwa, and his comrades denied the charges, but were imprisoned for over a year before being found guilty and sentenced to death by a specially convened tribunal, hand-selected by General Sani Abacha, on 10 November 1995. The activists were denied due process and upon being found guilty, were hanged by the Nigeria state. (The Guardian, 2009).

The executions were met with an immediate international response. The trial was widely criticized by human rights organizations and the governments of other states, who condemned the Nigerian government's long history of detaining their critics, mainly pro-democracy and other political activists. The Commonwealth of Nations, which had also plead for clemency, suspended Nigeria's membership in response. The United States, the United Kingdom, and the EU all implemented sanctions, but not on petroleum (Nigeria's main export).

Shell claimed to have asked the Nigerian government for clemency towards those found guilty, but its request was refused. However, a 2001 Greenpeace report found that "two witnesses that accused them (Saro-Wiwa and the other activists) later admitted that Shell and the military had bribed them with promises of money and jobs at Shell. Shell admitted having given money to the Nigerian military, who brutally tried to silence the voices which claimed justice". (Greenpeace, 2001).

By 2006, the situation in Ogoniland has eased significantly, assisted by the transition to democratic rule in 1999. However, no attempts have been made by the government or an international body to bring about justice by investigating and prosecuting those involved in the violence and property destruction that have occurred in Ogoniland, (Human Rights Watch, 2002). Although a class action lawsuit has been brought against Shell by individual plaintifis in the US. (Corporate Social Responsibility News, 2002).

\section{(b) The Ijaw-Itsekiri Conflicts (1997)}

The late 1990s saw an increase in the number and severity of clashes between militants of the Ijaw ethnic group, the largest in the entire Delta region with a population of over 7 million, and those of Itsekiri origin whose number is only about 450,000 . The conflict between the two groups has been particularly intense in the major town of Warri. While the Ijaw and the Itsekiri have lived harmoniously alongside each other for centuries, the Itsekiri were first to make contact with European traders, as early as the $16^{\text {th }}$ century, and they were more aggressive both in seeking Western education and in using the knowledge acquired to press their commercial advantages; until the arrival of Sir George Goldie's National Africa Company (later renamed the Royal Niger Company) in 1879, Itsekiri chieftains monopolized trade with Europeans in the Western Niger region. Despite the loss of their monopoly, the advantages already held by the Itsekiri ensured that they continued to enjoy a superior position to that held by the Ijaw, breeding in the latter a sense of resentment at what they fell to be colonial favoritism towards the Itsekiri.

The departure of the British at independence did not lead, as might have been expected, to a decrease in tensions between the Ijaw and the Itsekiri. With the discovery of large petroleum reserves in the Niger Delta region in the late 1950s, a new bone of contention was introduced, as the ability to claim ownership of a given piece of land now promised to yield immense benefits in terms of jobs and infrastructural benefits to be provided by the petroleum companies. Despite this new factor, rivalry between the Ijaw and the Itsekiri did not actually escalate to the level of violent conflict between the two groups until the late 1990s, when the death of General Sani Abacha in 1997 led to a re-emergence of local politics.

The issue of local government ward allocation has proven particularly contentious, as the Ijaw feel that the way in which wards have been allocated ensures that their superior numbers will not be reflected in the number of wards controlled by politicians of Ijaw ethnicity. Control of the city of Warri, the largest metropolitan area in Delta State and therefore a prime source of political patronage, has been an especially fiercely contested prize. This has given birth to heated disputes between the Ijaw, the Itsekiri and the Urhobo about which of the three groups are "truly" indigenous to the Warri region, with the underlying presumption being that the "real" indigenes should have control of the levers of power, regardless of the fact that all three groups enjoy ostensibly equal political rights in their places of residence 


\section{(c) The Ijaw unrest (1998-1999)}

The December 1998 All Ijaw Youths Conference crystallized the Ijaws' struggle for petroleum resource control with the formation of the Ijaw Youth Council (IYC) and the issuing of the Kaiama Declaration. In it, long-held Ijaw concerns about the loss of control of their homeland and their own lives to the oil companies were joined with a commitment to direct action. In the declaration, and in a letter to the companies, the Ijaws called for oil companies to suspend operations and withdraw from Ijaw territory. The IYC pledged "to struggle peacefully for freedom, self-determination and ecological justice", and prepared a campaign of celebration, prayer, and direct action, Operation Climate Change, beginning December 28.

In December 1998, two warships and 10-15,000 Nigerian troops occupied Bayelsa and Delta states as the Ijaw Youth Congress (IYC) mobilized for Operation Climate Change. Soldiers entering the Bayelsa state capital of Yanagoa announced they had come to attack the youths trying to stop the oil companies. On the morning of December 30, two thousand young people processed through Yanagoa, dressed in black, singing and dancing. Soldiers opened fire with riffles, machine guns, and tear gas, killing at least three protesters and arresting twenty-five more. After a march demanding the release of those detained was turned back by soldiers, three more protesters were shot dead including Nwachuku Okeri and Ghadafi Ezeifile. The military declared a state of emergency throughout Bayelsa state, imposed a dusk-to-dawn curfew, and banned meetings. At military roadblocks, local residents were severely beaten or derained. At night, soldiers invaded private homes, terrorizing residents with beatings and women and girls with rape.

On January 4, 1999 about hundred soldiers from the military base at Chevron's Escravos facility attacked Opia and Ikiyan, two Ijaw communities in Delta State. Bright Pablogba, the traditional leader of Ikiyan, who came to the river to negotiate with the soldiers, was shot along with a seven-year-old girl and possibly dozens of others. Of the approximately 1,000 people living in the two villages, four people were found dead and sixty-two were still missing months after the attack. The same soldiers set the villages ablaze, destroyed canoes and fishing equipment, killed livestock, and destroyed churches and religious shrines.

Nonetheless, Operation Climate Change continued, and disrupted Nigerian oil suppliers through much of 1999 by turning off valves through Ijaw territory. In the context of high conflict between the Ijaw and the Nigerian Federal Government (and its police and army), the military carried out the Odi massacre, killing scores if not hundreds of Ijaws.

Subsequent actions by Ijaws against the oil industry included both renewed efforts at nonviolent action and attacks on oil installations and foreign oil workers. (Online Nigeria, 2009).

(d) The Creation of the Niger Delta Development Commission (2000)

The Niger Delta Development Commission (NDDC) was established by President Olusegun Obasanjo with the sole mandate of developing the petroleum-rich Niger-Delta region of southern Nigeria. Since its inauguration, the NDDC has focused on the development of social and physical infrastructures, ecological/environmental remediation and human development.

\section{(e) The Emergence of armed groups, militancy and oil violence in the Region (2003-2004)}

The ethnic unrest and conflicts of the late 1990s (such as those between the Ijaw and Itsekiri), coupled with a spike in the availability of small arms and other weapons, led increasingly to the militarization of the Delta. By this time, local and state officials had become involved by offering financial support to those paramilitary groups they believed would attempt to enforce their own political agenda. Conflagrations have been concentrated primarily in Delta and Rivers States.

Prior to 2003, the epicenter of regional violence was Warri. However, after the violent convergence of the largest military groups in the region, the Niger Delta People's Volunteer Force (NDPVF) led by Mujahid Dokubo-Asari and the Niger Delta Vigilante (NDV) led by Ateke Tom (both of which are comprised primarily of Ijaws), conflict became focused on Port Harcourt and outlying towns. The two groups dwarf a plethora of smaller militias supposedly numbering more than one hundred. The Nigerian government classified these groups as "cults", many of which began as local university fraternities. The groups have adopted names largely based on Western culture, some of which include Icelanders, Greelanders, KKK, and Vultures. All of the groups are constituted mostly by disaffected young men from Warri, Port Harcourt, and their sub-urban areas. Although the smaller groups are autonomous from within, they have formed alliances with and are largely controlled from above by either Asari and his NDPVF or Tom's NDV who provided military support and instruction.

The NDPVF which was founded by Asari, a former president of the Ijaw Youth Council, in 2003 after he "retreated into the bush" to form the group with the explicit goal of acquiring control of regional petroleum resources. The NDPVF attempted to control such resources primary through oil "bunkering", a process in which an oil pipeline is tapped and the oil extracted onto a barge. Oil corporations and the Nigerian state point out that bunkering is illegal; militants justify bunkering, saying they are being exploited and have not received adequate 
profits from the profitable but ecologically destructive oil industry. Bunkered oil can be sold for profit, usually to destinations in West Africa, but also abroad. Bunkering is a fairly common practice in the Delta but in this case the militia groups are the primary perpetrators. (Human Rights Watch, 2002).

The intense confrontation between the NDPVF and NDV seems to have been brought about by Asari's political falling out with the NDPVF's financial supporter Peter Odili, governor of Rivers State following the April 2003 local and state elections. After Asari publicly criticized the election process as fraudulent, the Odili government withdrew its financial support from NDPVF and began to support Tom's NDV, effectively launching a paramilitary campaign against the NDPVF. (Wikipedia, 2009).

Subsequent violence occurred chiefly in reverine villages southeast and southwest of Port Harcourt with the two groups fighting for control of bunkering routes. The conflagrations spurred violent acts against the local population, resulting in numerous deaths and widespread displacement. Daily civilian life was disrupted, forcing schools and economic activity to shut down and resulting to widespread property destruction.

The state campaign against the NDPVF emboldened Asari who began publicly articulating populist, antigovernment views and attempted to frame the conflict in terms of pan-Ijaw nationalism and "selfdetermination". Consequently the state government felt the escalated the campaign against him by bringing in police, army, and navy forces that began occupation of the Port Harcourt in June 2004. The government forces collaborated with the NDV during the summer, and were seen protecting NDV militiamen from attacks by the NDPVF. The state forces failed to protect the civilian population from the violence and actually increased the destruction of citizens' livelihood. The Nigerian state forces were widely reported to have used the conflict as an excuse to raid homes, claiming that innocent civilians were cahoots with the NDPVF also accused the military of conducting air bombing campaigns against several villages, effectively reducing them to rubble, because it was believed to be housing NDPVF soldiers. The military denies this, claiming they engaged in aerial warfare only once in a genuine effort to wipe out an NDPVF strong hold.

Innocent civilians were also killed by NDPVF forces firing indiscriminately in order to engage their opponents. At the end of August 2004 there were several particularly brutal battles over the Port Harcourt waterfront; some residential slums were completely destroyed after the NDPVF deliberately burning down buildings. By September 2004, the situation was rapidly approaching a violent climax which caught the attention of the international community. (Human Rights Watch, 2002).

\section{NIGERIAN GOVERNMENT INTERVENTION TO RESOLVE THE CONFLICT (2007-2011)}

The Niger Delta Region has over the years continued to experience growing unrest. This as a result of some of the negative aspects of our socio-political evolution. Due to acts of omission and commission, successive governments at national, state and local levels have failed to do what they ought to have done; and in some cases done what they should not have done. It is for these lapses that some groups and individuals have resorted to armed confrontation with constituted authority. Besides, some opportunists have also taken advantage of the milieu to commit crimes against humanity and government. Unfortunately, many innocent souls have been lost while properties have been destroyed. Losses of revenue to government as a result of these acts of lawlessness are staggering. Despite this unpleasant situation, the federal government of Nigeria's president in 2007 decided to grant amnesty to all those involved in genuine agitation and to restore law and order and accelerate the development of our country. It is against this background that the Presidential Committee on Amnesty was set up to prepare a step-by-step framework for amnesty and complete disarmament, demobilization and reintegration in Niger Delta with appropriate time lines.

The amnesty which expired on October 2, 2009, has been generally acclaimed as a huge success. It has ushered in the cessation of armed conflict and wanton destruction of lives and properties and other forms of criminality in the region. With the large number of assorted arms surrendered, a steady return to social cohesion and decency in the region is assured. Besides, there is the economic angle to this. Nigeria's oil output has increased from about 1.3 million barrels per day in July to about 1.84 million barrels per day as at September (News watch, November 9, 2009).

Nigeria has a potential of three million barrels per day and that production level is achievable in the next few years if we maintain the present peace efforts. The electricity situation has continued to improve as well. Even the national and international image of Nigeria has improved since the granting of amnesty in the Niger Delta Region. As a member of the United Nations Security Council, speaking and working for peace all over the world is a responsibility we must be identified with among the comity of nations. With the expiration of the period of amnesty on October 4, 2009, the amnesty programme has entered a critical stage of implementation. This is the Rehabilitation and Reintegration phase which focuses on the ex-militants who have unconditionally embraced amnesty, renounced militancy and surrendered their arms. The challenge is to ensure that they are fully resettled to prevent them from returning to the creeks. This aspect of the amnesty involves reorientation, rehabilitation and capacity building, training and skills acquisition. ther efforts by the government to resolve the conflict, are as follows:- 
(a) Training/Skills Acquisition for the Ex-militants:

(b) Infrastructural Development of the Region

(c) Dialogue/Continuous Engagement

(d) The multinational oil companies to review their policies and operational techniques to meet global best practices in the oil and gas industry.

(e) Equity Participation by Oil producing Communities

For trust community to benefit from the proposed policy, the following three conditions must be satisfied:-

(1) Such community must have evidence of proven oil reserve or gas in their locality.

(2) It must have oil facilities, including pipelines either cited or passing through the area.

(3) Residents of such community must be identified as bona fide residents of the area before they benefit from the trust fund.

\section{LEGISLATION AND DECISIONS OUTSIDE NIGERIA: A COMPARATIVE ANALYSIS}

Due to the hazardous and adverse effect of pollution, developed and European countries have been able to make advanced legislations on this matter (Uchegbu, 1984).

In Canada, for example, the Alberta Oil and Gas Conservation Regulation and the Oklahoma Regulations of Oil are cases in point. The British Oil Pollution Act 1971, is very specific on sanctions against pollution and makes the discharge of oil into waters a criminal offence. Sections 1 and 2 of that Act (British Oil Pollution Act, 1971) provides that:

It is an offence to develop any kind of oil into the sea outside the United Kingdom waters from a ship registered in the United Kingdom or into the sea within the United Kingdom territorial waters and inland waterways. The Act makes the owner or master of the ship or both of them jointly guilty of an offence if the discharge is from land, liability rest on the occupier. The penalty for an offence under this section is $£ 50,000$ fine or summary conviction".

Under customary international law, in the Arbitral Tribunal in the Trail Smelter Case (R.I.A.A, 1940) it was decided that:

No state has the right to use or permit the use of his territory in such a manner as to cause injury on or the territory of another or to the properties of persons therein.

It has been argued that this obligation which, in this case, was applied to damages caused in the United States of America by the emission of noxious gases from the factory in Canada applies in relation to pollution of the sea and that a state is obliged to ensure that vessels under its flag do not cause injury or damage to other states by the pollution of the sea. Controversial as this argument has been under customary international law, the principle has been entrenched in Treaty laws.

In the Geneva Convention of the High Seas 1958, Article 25-38 and the new International Convention (Montego Bay Convention) 1982, all coastal states are enjoined to draw-up regulations to prevent pollution of the sea by the discharge of oil from ships or pipeline or any other sources arising from exploitation of the seabed resources. Mention must be made of International Maritime Organisation in the prevention of the pollution of the sea by oil (Oil Pollution Casualties 1969).

In the case of offshore pollution, municipal laws may find it difficult to provide for adequate compensation, especially if the pollution is outside Nigeria territorial waters, but have its effect extended into his territory. The difficulty stems from three reasons:-

(1) Under traditional international law given expression in the Geneva Convention of 1958, ships on the High Seas are subject to the jurisdiction only of the flag state. In the Towrey Cayon Incidence (61.L.M. 1967), a Liberian super tanker ran aground off the coast of Cromwalk and lost 60,000 tons of its 119,000 tons of oil and the tank was burnt down completely. The resulting pollution damage was paid to British and French coast. Sister ships of the company avoided British and French Port for a long time, but a sister ship of the same company was arrested in Singapore in 1969. In the end, the owner of the Towrey Cayon agreed and settled British government to the tune of $£ 3,000,000$ (three million pounds sterling).

In the Amoco Cadiz Case, a Liberian tanker in 1978 was wrecked on the coast of Bitany and lost almost all its cargoes of 230,000 tons of crude oil. French claims alone amounted to $\$ 2.2$ billion (two billion two million dollars). The Amoco Cadiz Incidence influenced the drafting on the relevant provision of pollution in the 1982 Montego Bay Convention on the law of the sea.

(2) The second problem is that most municipal legal system based liability for injury or damage arising from oil on fault or negligence, and the onus is usually placed on the injured party to prove fault or negligence. 
This, invariably becomes a formidable task, especially for developing countries most of which lack expert witnesses.

(3) Ship owners are normally entitled to have an upper limit placed in their liability. Under the United Kingdom laws, the limit in the case of the Towrey Cayon, was $\$ 1.25$ million pounds, whereas the actual damage itself is assessed in the United Kingdom alone was about £3.4 million and that of France was over six million France. But because of the limitation in the law, it was reduced to $£ 1.25$ million. The Towrey Cayon Incidence has given impetus to the adoption at the international level of two conventions to take care of compensation for offshore pollution.

These are the International Convention on Civil Liability for Oil Pollution Damages, 1969 (9 LLM, 1970). This convention has adopted the municipal concept of strict liability. The result is to place strict liability on ship owners in respect to pollution damage, in view of the huge sums that is likely to be involved in such liability. In the United States of America, the maximum or upper minimum liability has been placed at $\$ 1.5$ million dollars per incidence. The second Convention for Compensation for Oil Pollution Damages, 1971 provides for the setting up of a fund in which to pay compensation to victims who have been unable to obtain a complete remedy under the first mentioned convention.

From the above legislation and decisions outside Nigeria, it is obvious that these laws are usually enforced once they are breached, quite unlike Nigeria where the enforcement of these laws are being hampered by governmental authorities. Also, there are no such laws in Europe or America that resembles our Land Use Act, Petroleum Act and other draconian laws where all lands are vested in the government. In Canada or the United States of America, for example, whoever own the land in which oil or gas are found, owns everything and will only be made to pay royalty to the government.

\section{Conclusion}

Taking into consideration the issues so far addressed in this study, it is obvious that there are adequate laws in Nigeria to punish violators for the crimes of corruption and violence in Nigeria. The Nigerian state and communities in the Niger Delta Region has not felt the positive impact of Globalisation. It appears that the present administration are desirous to redress and resolve the social pathologies and the injustices meted out to the oil communities in the region by successive governments and the multinational oil companies. Good governance, transparency, accountability, perseverance, sincerity of purpose and the rule of law are the keys to tackling these social pathologies in Nigeria.

\section{References}

[1]. Adaka Boro Centre - Still on the Niger Delta Question, Gbaramatu Massacre 2009 (7/27/2009 (On line) http//www.adakaboro.org/resources/articles/37-articles/96-ndqabati. Reuben Abati.

[2]. African Concord (1990), "The Oil Industries: Five Years of Remodelling", $3{ }^{\text {rd }}$ September, Vol.5 No.8.

[3]. Amini S., Arighi, G. Frank, A-G, and Wallerstein, I (1982), Dynamics o Global Crisis,

[4]. Brenner, R. (1977), The origins of Capitalist Development: A critique of "neo-Smithian"

[5]. Escober, A. (1995a) Encountering Development, Princeton: Princeton University Press.

[6]. Etikerentse, G. (1988), Nigerian Petroleum Law, London and Bassingstoke: Macmillan

[7]. Etim, W. (August 27, 2003), Oil Spillage Devastate Bayelsa Communities. Posted on Ijawnation@yahoogroups.com by Titoe Miriki. $8 / 27 / 03$

[8]. Giddens, A. (1991), Modernity and self-Identity, Cambridge: Polity

[9]. Harvey, D. (1989), The Conditions of Post-modernity, Oxford: Blackwell

[10]. Hoogvelt, A. (1997), Globalisation and Post Colonial World, London: Macmillan

[11]. Kiely, RR. (1994), "Development Theory and Industrilisation: Beyond the Impasse", Journal of Contemporary Asia 24:133.

[12]. Okaba, B.O. (2005), Petroleum Industry and the Paradox of Rural Poverty in the Niger Delta (Benin City: Ethiope Publishing Corporation).

[13]. Niger Delta Solidarity: A Post Petroleum Nigeria (online)12/15/2009 http://nigerdeltasolidarity. Wordpress.com/200911/29/a—postpetroluem-nigeria, posted by Sokari Ekine under conflict, Human Rights.

[14]. O'Brien, R. (1991), Global Financial Integration: The End of Geography, London: Pinter

[15]. Ohmae, K. (1991), The Borderless World, London: Fontana

[16]. Onimode, B. (2008), "Imperialism and Multinational Corporations: A Case Study of Nigeria.”Journal of Black Studies Vol. 9 , No. 2. Dec. 1978 p. 207.8 Dec 2008.

[17]. Radice, H. (1996), “The National Economy: A Keynesian Myth”, Capital and Class 22: 111-140

[18]. Tobias HALLER et al. (2000): Fossile Ressourcen, Erdolkonzerne and indigene Volker, Giessen: Focus Verlag, 105.

[19]. Uchegbu, A. (1984), "Movement of Hazardous Waste in Trans Boundary Laws", in Environmental Laws No.6 Vol.3.

[20]. Worsely, P. (1984), The Three Worlds, London: Weinderfield and Nicolson

\section{LEGISLATION}

Associated Gas Re-Injection Act, 1979 (as amended by Act, 2008)

Constitution of the Federal Republic of Nigeria, 1999

General Convention of the High Seas, 1958 
International Convention (Montego Bay Convention, 1982)

International Convention on Civil Liability for Oil Pollution Damages, 1969 (9 LLM, 1970)

Land Use Act, 1978

Mineral Ordinance, 1948

Mineral Oil (Safety R egulations) 1963

New York: Monthly Review Press

Oil Pollution Casualties, 1969

Petroleum Profit Tax Act, 1959

Petroleum Act, 1969

Petroleum (Drilling and Production Regulations, 1969)

The British Oil Pollution Act, 1971

Minerals Ordinance of 1914, Cap. 350, Laws of the Federation of Nigeria, 1990

Oil in Navigable Waters Act, Cap.338, Laws of the Federation of Nigeria, 1990

Petroleum Act, Cap 131, Laws of the Federation of Nigeria, 1990

Petroleum Act, Cap 131, Laws of the Federation of Nigeria, 1990 as amended by the Federal Environmental

Protection Agency Decree No. 59 of 1992 to include the following Regulations:

Petroleum Regulations

Petroleum (Drilling and Production) Regulations

Petroleum Refining Regulations

Oil Pipelines Act

Federal Environmental Protection Agency Act

Guidelines and Standards for Environmental Pollution Control in Nigeria

National Environmental Protection (Effluent Limitation) Regulations, 1991

National Environmental Protection (Pollution Abatement in Industries and

Facilities Generating Wastes) Regulations, 1991 - Section 1.15 of 1991

Environmental Impact Assessment Decree

Criminal Code Act

Harmful Waste (Special Criminal Provisions, Etc) Decree 1988

Sea Fisheries Decree

Territorial Waters Act

Explosives Act

Oil Terminal Dues Act

\section{DECIDED CASES}

Towrey Cayon Incidence (61 L.M.) 1967

Trail Smelter Case (R.I.A.A, 1940) 